\title{
Pengembangan Desain Produk dan Pemasaran Kelompok Usaha Kerajinan Tangan Berbahan Tali Kur di Desa Siwatu
}

\author{
Tutut Dwi Andayani ${ }^{1}$, Bayu Kurniawan ${ }^{2}$, Alfa Yuliana Dewi ${ }^{3}$ \\ ${ }^{1}$ Program Studi Akuntansi, Universitas Muhammadiyah Pekajangan Pekalongan, \\ ${ }^{2}$ Program Studi Manajemen,STIE AKA Semarang, \\ ${ }^{3}$ Program Studi Manajemen, Universitas Muhammadiyah Pekajangan Pekalongan \\ Email : atututdwi@yahoo.com, bayukurniawan3@gmail.com, alfayuliana@gmail.com
}

\begin{abstract}
Abstrak
Desa Siwatu memiliki total populasi 1.987 pria dan total 2.007 wanita dengan total populasi 3.994. Penduduk Siwatu memiliki mata pencaharian terbesar di sektor pertanian dengan total 811, industri berjumlah 110, perdagangan berjumlah 110 dan layanan berjumlah 95. Salah satu industri di Desa Siwatu adalah industri kerajinan rumah tangga yang dilakukan oleh kelompok PKK, yaitu kerajinan tangan bisnis pembuatan tas cantik yang terbuat dari tali kur. Saat ini hanya ada beberapa desain produk yang dibuat sehingga masih perlu dikembangkan menjadi berbagai jenis desain yang menarik perhatian publik. Selain itu, promosi media online juga belum maksimal karena kurangnya pengetahuan teknologi dan media sosial. Tujuan dari pengabdian masyarakat adalah untuk menciptakan model desain tas yang kreatif dan indah, untuk meningkatkan SDM wanita untuk menjadi terampil dalam menciptakan produk-produk kreatif, meningkatkan produksi, pelatihan akuntansi UMKM, sistem penjualan online dan offline, meningkatkan pengetahuan manajemen bisnis, pemasaran bisnis, dan informasi tentang mengakses bantuan bisnis. Sedangkan targetnya adalah terwujudnya wirausaha mandiri yang mampu menciptakan lapangan kerja bagi masyarakat sekitar. Metode yang digunakan dalam program pengabdian masyarakat ini adalah metode Participatory Rural Apraissal (PRA) yang merupakan metode pendekatan dalam proses pemberdayaan dan peningkatan partisipasi masyarakat
\end{abstract}

Kata Kunci: Ibu-ibu PKKK, Produksi Tas, Desain, Pemasaran, Akuntansi

\section{PENDAHULUAN}

Salah satu industri di Desa Siwatu yaitu industri kerajinan rumah tangga yang dilakukan oleh kelompok Ibu-Ibu PKK yakni usaha kerajinan tangan membuat tas cantik berbahan tali kur. Usaha ini menjadi unggulan bagi kelompok Ibu-Ibu PKK dan Pemerintah Desa Siwatu. Bagi Ibu-Ibu PKK membuat tas berbahan tali kur sangat fleksibel karena bisa dikerjakan sambil mengurus kegiatan rumah tangga. Alat dan bahan bakupun mudah didapatkan, hanya diperlukan ketrampilan tangan dan ketelitian dalam membuat produk tas cantik. Usaha ini juga memiliki peluang yang sangat besar karena masih sedikit usaha yang sama ada di Kabupaten Batang dan sekitarnya. 
Usaha kerajinan tangan ini pada awalnya hanya dikenal di tingkat Kecamatan Wonotunggal karena baru di perkenalkan melalui perkumpulan ibu-ibu PKK Desa Siwatu Kecamatan Wonotunggal Kabupaten Batang. Adapun minat konsumen tas ini masih di dominasi oleh Ibu-Ibu karena di perkenalkan melalui Ibu-Ibu PKK dengan desain tas sesuai selera Ibu-Ibu sehingga ke depannya perlu desain yang kreatif guna diminati oleh anak muda.

Kondisi awal lainnya dari usaha kerajinan tangan ini adalah keterbatasan keterampilan Ibu-Ibu dalam mengembangkan desain serta belum adanya pendampingan dari pihak-pihak yang berkompeten dalam bidang kerajinan tangan. Disamping itu juga berkaitan dengan pemasaran hasil produk tas yang masih terbatas yaitu melalui getuk tular, belum bisa memaksimalkan pemasaran melalui media online.

Adapun permasalahan yang dihadapi usaha tersebut antara lain keterampilan dalam memproduksi masih hanya beberapa model tas, menjahit furing dan resleting tas masih mengandalkan pihak ketiga sehingga mempengaruhi waktu produksi, minimnya pengetahuan tentang manajemen usaha, lemahnya fungsi pemasaran dalam mempromosikan dan menjual hasil kerajinan dan kurangnya modal dan informasi mengakses bantuan dana usaha dari pemerintah dan swasta.

\section{METODE}

Metode pelaksanaan kegiatan dengan menggunakan metode pemberdayaan masyarakat partisipatif (Muslim, 2007) atau disebut Participatory Rural Apraissal (PRA) yaitu sebuah teknik pendekatan untuk memberdayakan dan meningkatkan partisipasi masyarakat, dimana dalam kegiatan tersebut dilakukan penekanan yaitu adanya keterlibatan masyarakat dalam rangkaian keseluruhan kegiatan. Rencana kegiatan yang menunjukan langkah-langkah solusi atas persoalan pada kedua aspek utama yaitu:

a. Pengenalan masalah/kebutuhan dan potensi serta penyadaran.

b. Penetapan prioritas yaitu pada Masalah yang telah dilakukan identifikasi untuk selanjutnya dirangking urut dari masalah yang paling besar sampai ke masalah yang kecil.

c. Penentuan solusi pemecahan masalah.

d. Pembuatan Desain Produk Tas Kreatif.

e. Branding Produk

f. Pembuatan website

g. Pembuatan Media Pemasaran. 


\section{HASIL DAN PEMBAHASAN}

\section{Forum Grup Diskusi (FGD)}

Tahap ini dilakukan dengan identifikasi terhadap berbagai permasalahan yang dihadapi mitra serta menyiapkan semua sarana yang akan digunakan untuk melaksanakan kegiatan. Dalam mengatasi permasalahan yang dilakukan dengan cara menetapan prioritas masalah-masalah yang sudah teridentifikasi selanjutnya dirangking urut dari masalah yang paling besar sampai ke masalah yang kecil. Adapun permasalahan utama yang dihadapi adalah minimnya desain produk tas. Kemudian permasalahan berikutnya adalah kemampuan manajemen usaha ala kadarnya dan terakhir adalah minimnya pemasaran produk.

2. Desain Produk

Tahap ini dilakukan dengan melakukan analisis referensi dari media elektronik, wawancara anak muda dan ibu-ibu hingga calon konsumen dalam membuat model yang disukai dan diminati oleh masyarakat. Saat ini model tas tali kur di Desa Siwatu berjumlah 30 buah. Adapun sampelnya sebagai berikut:

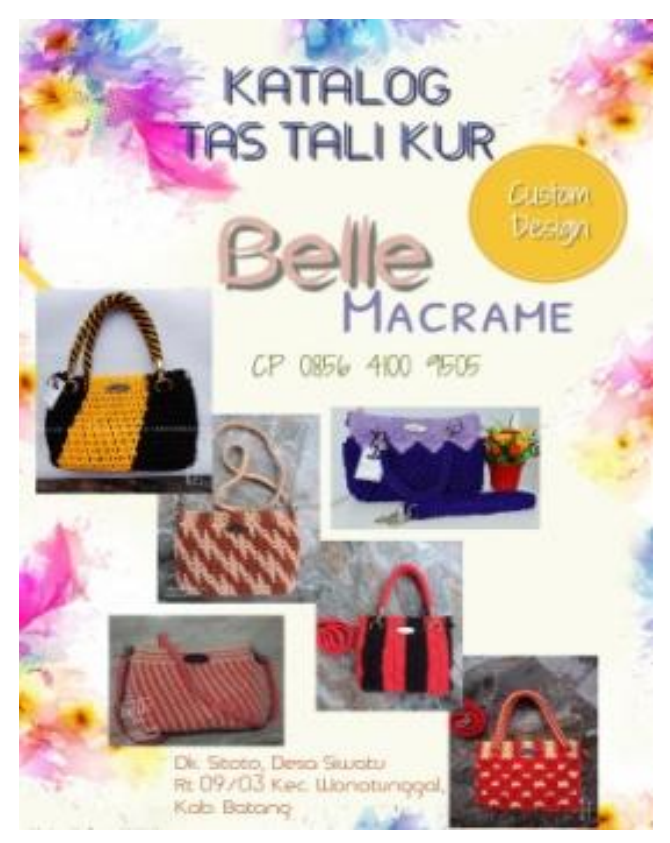

Gambar 1 Katalog Produk

3. Branding Produk

Tahap ini dilakukan penamaan merek tas guna dilakukan branding produk tas. Adapun nama merek tas tersebut adalah "Belle" yang memiliki arti "Aura Kecantikan". (Nastain, 2017) (Hendri Ali Ardi, 2017) (Idris, 2008) 

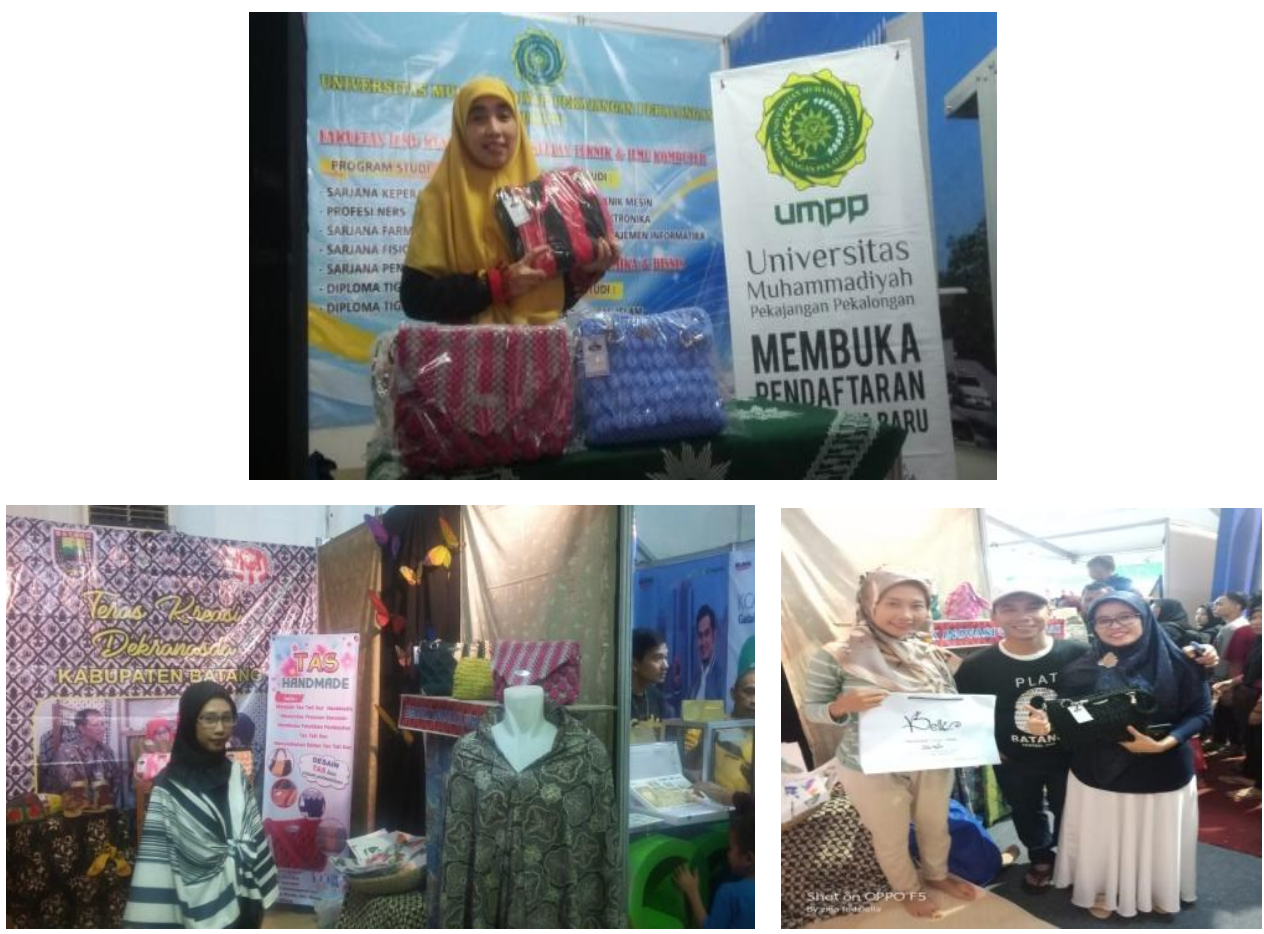

Gambar 2 Mengikuti Pameran

4. Website

Tahap ini yaitu pembuatan website Adapun saat ini masih dalam bentuk website blogspot dengan alamatnya sebagai berikut : http://belletastalikur.blogspot.com. Hal ini dibuat guna memudahkan dalam hal pemasaran dan pengenalan produk tas secara online.

5. Media Pemasaran

Tahap ini telah dibuatkan media pemasaran offline (Suryani, 2014) seperti kartu nama, paperbag, brosur dan pameran, sedangkan media online (Ahyuna, 2013) dibuatkan akun WA, IG dan facebook. Adapun contoh gambarnya sebagai berikut:
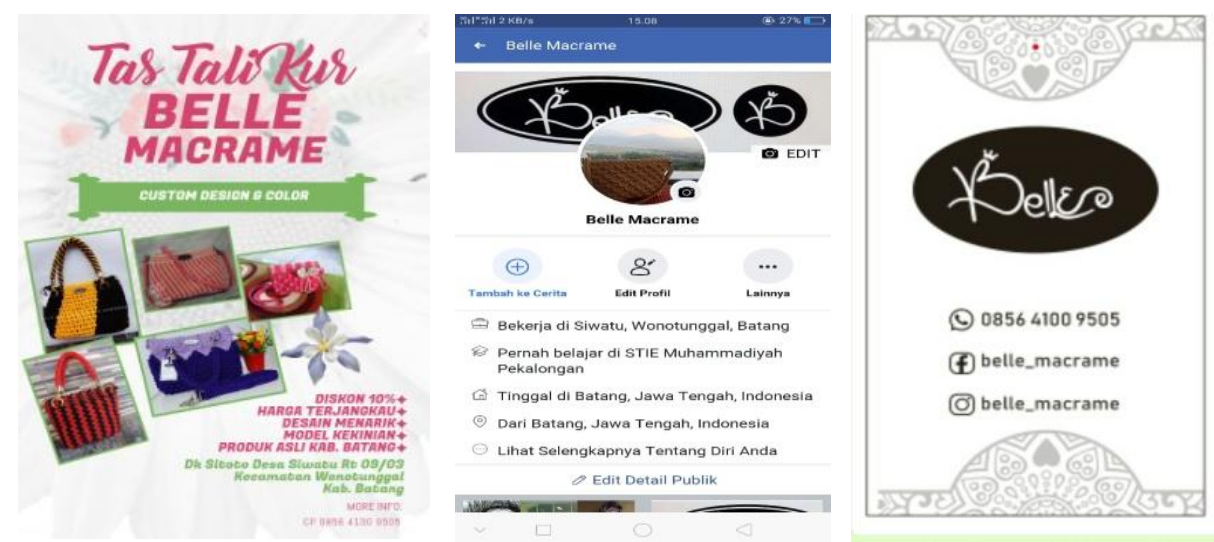

Gambar 3 Media leaflet dan sosial media 


\section{KESIMPULAN}

Pendampingan PKM yaitu dalam upaya pengembangan desain produk dan pemasaran di Desa Siwatu Kecamatan Wonotunggal Kabupaten Batang telah mampu meningkatkan pengetahuan, dan keterampilan dalam menambah desain produk, pembuatan laporan keuangan, penggunaan berbagai media on line dalam pemasaran. Hal berdampak pada semakin dikenalnya produk kerajinan tas belle serta adanya peningkatan penjualan tas belle dari waktu ke waktu serta terjalinnya kerja sama dan kepercayaan dari beberapa instansi di Kabupaten Batang.

Kepercayaan dari pelanggan dan beberapa instansi yang terus meningkat hendaknya terus dipertahankan dan ditingkatkan dengan tetap menjaga kualitas sehingga usaha kerajinan tangan ini dapat terus berkembang menjadi besar dan dikenal tidak hanya di dalam negeri tetapi juga sampai ke mancanegara.

\section{DAFTAR PUSTAKA}

[1] Ahyuna, M. D. (2013, Januari - Maret). Pemanfaatan Internet Sebagai Media Promosi Pemasaran Produk Lokal Oleh Kalangan Usaha Di Kota Makasar. Jurnal Komunikasi KAREBA, 2, 30 - 41.

[2] Hendri Ali Ardi, S. S. (2017). Pemberdayaan Usaha Masyarakat Melalui Branding Produk. Jurnal Untuk Mu negeRI, Universtias Muhammadiyah Riau, 1, 55-60.

[3] Idris, K. (2008). Membuat Sebuah Merek, Pengantar Merek Untuk Usaha Kecil Menengah. Jakarta: Kamar Dagang dan Industri Indonesia.

[4] Muslim, A. (2007). Pendekatan Partisipatif Dalam Pemberdayaan Masyarakat. Jurnal Aplikasi Ilmu-ilmu Agama, VIII, 89-103.

[5] Nastain, M. (2017, April 1). Branding dan Eksistendi Produk (Kajian Teoritik Konsep Branding dan Tantangan Eksistensi Produk). CHANNEL, Universitas Mercu Buana Yogyakarta, 5, 14-26.

[6] Suryani, I. (2014, April). Pemanfaatan Media Sosial Sebagai Media Pemasaran Produk dan Potensi Indonesia Dalam Upaya Mendukung ASEAN Community 2015. (Studi Social Media Marketing Pada Twitter Kemenparekraf RI dan Facebook Disparbud Provinsi Jawa Barat). Jurnal Komunikasi, ISSN 1907-898X, Akademik Komunikasi Bina Sarana Informatika, 8, 123-139. 